\title{
ANALISIS PEMEROLEHAN BAHASA PERTAMA PADA ANAK USIA SATU TAHUN SAMAPAI USIA LIMA TAHUN DI KELURAHAN CIGINTUNG
}

\author{
Ajat Sudrajat \\ Sun Suntini \\ Program Studi Pendidikan Bahasa dan Sastra Indonesia \\ Fakultas Keguruan dan Ilmu Pendidikan Universitas Kuningan
}

\begin{abstract}
ABSTRAK
Pemerolehan bahasa pertama sangat penting bagi seorang anak karena akan menentukan penguasaan bahasa kedua dan bahasa selanjutnya. Khusus di Indonesia bahasa pertama selalu identik dengan bahasa daerah, misalnya orang Sunda bahasa pertamanya bahasa Sunda atau orang Jawa bahasa pertamanya bahasa Jawa, namun seiring berjalannya waktu banyaknya perkawinan campuran, modernisasi dll saat ini banyak ibu-ibu yang mengajarkan bahasa pertamanya bukan bahasa daerah tetapi bahasa Indonesia bahkan bahasa Asing misalnya bahasa Inggris, terutama di kota-kota besar seperti Jakarta, Bandung, Surabaya dan kota besar lainnya, tetapi tidak menutup kemungkinan kota kecil pun sudah mulai jarang yang mengajarkan bahasa pertamanya bahasa daerah, contohnya di Kabupaten Kuningan banyak orang tua yang mengajarkan bahasa pertama bahasa Indonesia. Penelitian dibidang pemerolehan bahasa sangat jarang dilakukan oleh karen itu peneliti tertarik untuk meneliti pemerolehan bahasa pertama pada anak. Rumusan masalah pada penelitian ini ada tiga yaitu (1)Bagaimanakah pemerolahan bahasa secara fonologis pada ujaran anak usia satu tahun sampai lima tahun di Kelurahan Cigintung ?(2) Bagaimanakah pemerolehan bahasa secara morfologis pada ujaran anak usia satu tahun samapai lima tahun di Kelurahan Cigintung ?(3) Bagaimanakah pemerolehan bahasa secara sintaksis pada ujaran anak usia satu tahun sampai lima tahun di Kelurahan Cigintung?tujuan dari penelitian ini adalah (1)Untuk mendeskripsikan pemerolahan bahasa secara fonologis pada ujaran anak usia satu tahun sampai lima tahun di Kelurahan Cigintung (2)Untuk
\end{abstract}


FON ; Jurnal Pendidikan Bahasa dan Sastra Indonesia

Volume 13 Nomor 2 Tahun 2018

mendeskripsikan pemerolahan bahasa secara morfologis pada ujaran anak usia satu tahun sampai lima tahun di Kelurahan Cigintung (3) Untuk mendeskripsikan pemerolahan bahasa secara sintaksis pada ujaran anak usia satu tahun sampai lima tahun di Kelurahan Cigintung.metode yang digunakan dalam penelitian ini yaitu deskriptif analitis. Teknik pemerolehan data dokumentasi dan wawancara. Hasil penelitian Hasil analisis pemerolehan bahasa secara fonologis pada anak usia satu sampai lima tahun di kelurahan cigintung rata-rata semua anak sama, untuk pemerolehan bunyi vokal paling banyak bunyi a misalnya pada kata aa, ayah, mau, minta, maen dll. bunyi konsonan dari usia satu sampai lima tahun paling banyak bunyi bilabial nasal (m) misalnya pada kata makan, minum, mau, mimi, maen dll. Berikutnya bunyi konsonan yang lumayan mereka kuasai yaitu bunyi bilabial hambat (p/b) misalnya pada kata bapa, abis, beyum,beli, bobo, papih dll. Bunyi glotal (h) misalnya kata ayah,rumah, mamih, sepedah, papih dll. Bunyi alveolar (t/d) misalnya pada kata teteh, duduk, mandi dll. Bunyi bilabial semivokal (y/w) misalnya pada kata ayah, ayam, beyum, warna dll.pemerolehan dibidang morfologis yaitu prefiks di- dan sufiks -nya, pengulangan seluruh dn sebagian, tidak ditemukan sisipan dan kata majemuk.pemerolehan dibidang sntaksis anak banyak menggunakn kalimat imperatif, deklaratif, interogatif dan sedikit kalimat negatif.

Kata kunci : pemerolehan bahasa pertama, anak usia satu sampai lima tahun.

\section{PENDAHULUAN}

Pemerolehan bahasa pada anak biasanya berlangsung antara usia nol hingga lima tahun, sebelum satu tahun seorang bayi sudah mengeluarkan bunyibunyi bahasa yang belum mempunyai arti, sekitar lima atau enam bulan bayi mulai belajar bicara satu kata tetapi belum mempunyai makna, usia satu tahun bunyi bahasa bayi mulai jelas, pada usia ini seorang ibu mulai memperkenalkan segala sesuatu yang ada di dalam atau sekitar rumah. Setiap anak memiliki perkembangan bahasa yang berbeda, ada yang 1,5 tahun sudah bisa bicara ada yang dua tahun bisa bicara bahkan ada yang tiga tahun baru lancar bicara, tetapi pada umumnya anak bisa bicara pada usia dua tahun itu pun masih banyak kosa kata yang belum dikuasai. Penguasaan kosa kata ini tergantung pembelajaran dari ibunya dan tingkat kecerdasan anak dalam memahami bahasa. Analisis tentang pemerolehan bahasa anak/bahasa pertama masih sangat minim, padahal ini sangat penting terutama untuk kalangan ahli 
FON ; Jurnal Pendidikan Bahasa dan Sastra Indonesia

Volume 13 Nomor 2 Tahun 2018

bahasa yang seharusnya mengetahui perkembangan terbaru dunia kebahasaan. Penulis sebagai dosen pengampu mata kuliah Teori Belajar Bahasa ingin meneliti pemerolehan bahasa pertama pada anak sebagai salah satu materi pada mata kuliah tersebut. Penelitian ini dianggap penting untuk mengetahui perkembangan terbaru dalam bidang pemerolehan bahasa anak.

Berbicara masalah fonologi tentu ada kaitannya dengan otak manusia dan kemampuan berbicara manusia. Perkembangan otak manusia berkaitan erat dengan perkembangan kemampuan berbicara yang konon mulai muncul pada saat primat mencapai tahap homo habilis sekitar dua juta tahun yang lalu pada saat otak mengalami pengembangan ukuran yang pesat.(Holloway, 1996:93; dover 1999:78) dalam soenjono dardjowiddjojo (2000:53).

Morfologi merupakan bagian dari ilmu bahasa yang mempelajari selukbeluk bentuk kata, juga menyelidiki kemungkinan adanya perubahan golongan dan arti kata yang timbul sebagai akibat perubahan bentuk kata (Ramlan, 1983:21). Satuan yang paling kecil diselidiki oleh morfologi ialah morfem yang paling besar berupa kata.

Morfem adalah satuan gramatik yng paling kecil dan tidak mempunyai satuan lain sebagi unsurnya. Kata merupakan dua macam satuan satuan fonologi dan satuan gramatik, atau kata merupakan satuanbebas yang paling kecil contoh rumah, mobil, gedung dll. Dalam morfologi ada tiga bahasan utama yaitu afiksasi yaitu satuan gramatik terikat dalam suatu kata merupakan unsur bukan kata dan bukan pokok kata. Afiks terdiri dari :

1. Prefiks (meN-, ber-, di-, ter-, peN-, pe-,se-, per-, pra-, ke-, a-, maha-, para-)

2. Infiks (el-, er-, em-)

3. Sufiks (-kan, -an, -i,-nya,-wan,-wati,is,-man,-da, -wi)

4. Simulfiks (ke-an, pen-an, per-an, beran, se-nya)

Kedua proses pengulangan yaitu pengulangan satuan gramatik baik seluruhnya maupun sebagian baik dengan variasi fonem maupun tidak. Misalnya rumah-rumah, mobil-mobil, gedunggedung dll. Ketiga proses pemajemukan yaitu gabungan dua kata yang menimbulkan suatu kata baru. Misalnya meja makan, keras hati, panjang tangan dll. Sintaksis merupakan cabang dari ilmu bahasa yang membicarakan seluk-beluk wacana, kalimat, kausa dan frasa (ramlan, 2005:18). Dalam sintaksis lebih banyak dibicarakan tentang kalimat diantaranya 
kaliamt berklausa dan kalimat tak berklausa, kalimat tanya, kalimat berita, dan kalimat suruh.

Dalam penelitian ini pemerolehan bahasa secara sintaksis fokus pada pemerolehan kalimat deklarati (kalimat berita),imperatif (kalimat perintah), interogatif(kalimat pertanyaan), dan negatif(bukan, tidak, belum, jangan).

\section{METODELOGI PENELITIAN}

\section{Metode Penelitian}

Adapun metode penelitian yang digunakan adalah deskriptif kualitatif, yaitu metode penelitian yang berusaha untuk menggambarkan dan mengintrepretasi objek sesuai dengan apa adanya.

\section{Subjek Penelitian}

Subjek penelitian adalah ujaran anak usia satu sampai lima tahun di Perum Ciharendong Kencana dengan jumlah anak 30 orang.

\section{Teknik Pengumpulan Data}

Teknik pengumpulan data yang digunakan adalah;

1. Dokumentasi

Mendokumentasikan ujaran anak dengan cara direkam kemudian hasil rekaman diketik.

2. Wawancara
Wawancara dilakukan terhadap orang tua anak yang diteliti mengenai perkembangan bahasa anak tersebut.

\section{Teknik Analisis Data}

Data dianalisis berdasarkan

instrumen yang telah dibuat oleh peneliti berdasarkan teori.

\section{HASIL PENELITIAN}

1. Hasil analisis pemerolehan bahasa secara fonologis pada anak usia satu sampai lima tahun di kelurahan cigintung rata-rata semua anak sama. Berikut hasil analisis pemerolehan bahasa secara fonologis.

- Alfarezel Shaqeel W. usia 1 tahun 6 bulan berdasarkan hasil observasi peneliti dan wawancara terhadap ibunya secara umum perkembangan fisik cukup bagus bahkan dalam usia 12 bulan sudah bisa berjalan walaupun belum ajeg. Pemerolehan bahasa berdasarkan fonologi banyak mengahasilkan bunyi vokal a misalnya pada kata aa, papah, mamam, mamah dan mam. Kata aa untuk menyapa kakaknya yang lakilaki dalam pengucapannya masih kurang jelas.bunyi vokal yang lainnya yaitu u dan e pada kata bunyi ue maksudnya ee (mau buang air besar) serta vokal o pada kata bob-bob untuk bobo (tidur). 
Sedangkan bunyi konsonan yang keluar adalah bunyi bilabial hambat (p) pada kata papah, dan bilabial nasal pada kata mamah (ibunya) dan mamam (makan), berikutnya bunyi yang keluar glotal (h) pada kata mamah, papah.

- Muhammad Firqi Haqi el Mumtaz usia 2 tahun 6 bulan perkembangan fisik normal bahkan dapat dikatakan perkembangannya sangat cepat, 12 bulan bisa jalan 1,5 tahun bisa bicara jelas dan sekarang 2,5 tahun sudah menghasilkan kalimat-kalimat pendek . untuk pemerolehan fonologi bunyi vokal yang dihasilkan yaitu a pada kata abi,uwa, jajan, acim (ice cream), tatut (takut), wat (lewat), iyah (iya) dan masih banyak lagi, vokal i pada kata abi, acim, iyah, umi, pegi, pipi.vokal u pada kata umi, uwa, ueh, beyum, badut. Vokal e pada kata teteh, ueh (kue), nenen, neh, pegi dan beyum.vokal o pada kata bobo,obot, buyok. Sedangkan pemerolehan konsoan menghasilkan bunyi bilabial nasal (m) pada kata umi, beyum, dan ecim, bunyi bilabial hambat (b/p) pada ata pegi, abi, badut, bunyi konsonan alveolar (n) pada kata nenen, neh, bunyi velar semivokal (y) pada kata iyah dan beyum, bunyi glotal (h) pada kata neh, teteh, ueh. Bunyi alveolar hambat (t) pada kata teteh, wat, tatut. Bunyi konsonan bilabial semivokal pada kata uwa, bunyi konsonan alveolar (d) pada kata badut. Secara umum pemerolehan fonologinya hampir semua ada baik vokal maupun konsonan.

- Hafizh Muflih usia3 tahun 2 bulan perkembangan fisik normal. Bunyi vokal yang diperoleh yaitu bunyi a pada kata mamah, kakam (makan), nangis, bangun dan main. Bunyi vokal i pada kata minum, pipis, nangis, main. Bunyi vokal u pada kata minum, duduk,bangun. Bunyi vokal e pada kata ee, teteh, sebentay. Bunyi vokal o pada kata bobo dan obot. Sedangkan bunyi konsonan yang keluar yaitu bilabial nasal (m) mamah, kakam, main, minum. Bunyi konsonan bilabial hambat $(\mathrm{p} / \mathrm{b})$ pada kata bangun, sebentay, bobo, obot. Bunyi konsonan alveolar (t) pada kata obot, teteh, sebentay. Bunyi konsonan velar (y) pada kata sebentay. Bunyi alveolar (d)pada kata duduk. Bunyi glotal (h) pada kata teteh. Sama dengan anak yang 
lain bunyi yang dihasilkan vokal didominasi a dan konsonan bilabial.

- Anisa khumaira Azzahra usia4 tahun 8 bulan perkembangan fisik normal. Pemerolehan bunyi vokal a yaitu pada kata mamah, makan,mau, mandi, laper, bunda. Bunyi vokal i pada kata mandi, tidur, nyanyi, wacibang, api. Bunyi vokal u pada kata bunda, kucing, tidur. Bunyi vokal e pada kata laper, menggambar, beko, keleta. Bunyi vokal o pada kata beko, coot (copot), lobot (robot). Bunyi konsonan yang dihasilkan yaitu bilabial nasal (m) pada kata mamah, makan, mau, mandi, sama, menggambar.bunyi bilabial hambat (p/b) pada kata laper, bunda, tidur, beko, lobot (robot). Bunyi glotal (h) pada kata mamah. Bunyi lveolar (t/d) pada kata mandi, tidur, dan bunda.

- Nauval Shidqi Alfahri usia 5 tahun 9 bulan, Perkembangan fisik normal. Pemerolehan vokal a pada kata aku, mau,makan, bunda,main,jajan,ayah, sepedah. Pemerolehan bunyi i pada kata minum, main,film, naik, ciki.bunyi vokal u pada kata aku, bunda, minum, mau, ikut.pemerolehan bunyi vokal e pada kata sepedah. Pemerolehan bunyi vokal o pada kata bobo dan nonton. Pemerolehan bunyi konsonan yaitu bunyi bilabial nasal (m) pada kata mau, makan, minum, main, film. Bunyi konsonan velar hambat $(\mathrm{k} / \mathrm{g})$ pada kata makan, naik, ciki,aku, ikut. Bunyi konsonan alveolar nasal (n) pada kata makan, bunda, main, jajan, minum, naik, nonton. Pemerolehan bunyi konsonan alveolar hambat (t/d) pada kata bunda, ikut, sepedah, nonton. Pemerolehan bunyi konsonan glotal (h) pada kata ayah. Pemerolehan bunyi alveopalatal (y) pada kata ayah.

2. Hasil analisis pemerolehan bahasa morfologis pada anak usia satu sampai lima tahun di kelurahan cigintung. Berikut pemerolehan bahasa anak secara morfologis:

- Pemerolehan prefiks di(diambil) mulai diucapkan oleh firqi dari usia dua tahun, sebelumn usia dua tahun ujaran belum bentuk kalimat masih per kata, setelah mulai menggunakan prefiks pasif struktur kalimat jadi berubah. Setelah dua tahun prefiks di- sering diucapkan dalam kalimat pendek. 
Kata dasar ambilin yaitu ambil seharusnya akhiran yang benar ambilkan bukan ambilin karena tidak ada ahiran -in yang ada ahiran -i, firqi menggunakan kata tidak baku dengan menggunakna ahiran-in.

- Prefiks di- digunakan firqi pada kata dibawa, biasanya digunakan untuk memberitahu sesuatu/makanan yang dibawa oleh kakaknya

- Kata uehnya (kuenya) klitiknynya digunakan oleh firqi ketika menyebutkan makanan

- Kata jalan-jalan merupakan jenis pengulangan seluruh kata ini termasuk kata kerja.bentuk dasarnya jalan. Banyu sudah bisa menggunakan pengulangan ini biasanya ahir pekan ketika mau keluar rumah.

- Kata obot-obotan juga termasuk pengulangan jenis sebagian karena yang diulang hanya sebagian.asal kata dari robt setelah diulang dan dibubuhi ahiran-an tadinya nomina menjadi verba

- Kata mobil-mobilan merupakan pengulangan sebagian asal kata dari mobil. Kata ini digunakan oleh hafizh untuk mengajak temannya bernama Firqi bermain mobil-mobilan.

- Kata beliin berasal dari kata beli ditambah bentuk -in sehingga membentuk verba, sedangkan kata mainan berasal dari kata main diberi imbuhan ahir -an sehingga membentuk nomina.

- Kata maen-maenin berasal dari kata maen diulang menjadi maen-maen lalu ditambah bentuk -in sehingga membentuk verba

- Kata jajanannya dari kata dasar jajan bentuk dasar jajanan dan diberi imbuhan ahir -nya menjadi jajanannya sehingga membentuk kata nomina

- Kata mewarnai dari kata dasar warna diberi imbuhan awal medan ahiran $\quad-\mathbf{i}$ sehingga membentuk verba. Kata permainan dari kata dasar main diberi imbuhan per- ahiran -an sehingga membentuk nomina.

3. Hasil analisis pemerolehan bahasa dibidang sintaksis terbagi menjadi empat yaitu kalimat deklaratif, kalimat imperatif, kalimat interogatif dan kalimat negatif, keempatnya ada pada ujaran anak-anak yang diteliti tidak semua anak yang diteliti pada 
bidang ini hanya usia tiga sampai lima tahun karena ujaran dalam bentuk kalimat biasanya diperoleh anak sekitar tiga tahun.dari penelitian ini kebanyakan anak.berikut pemerolehan bahasa secara sintaksis :

- Kalimat imperatif saah satunya ditandai dengan kata "ayo" seperti pada kalimat "fiqi ayo main" kalimat ini sering digunakn oleh anak-anak untuk meminta, mengajak dll.

- Kalimat interogatif/pertanyaan pada kalimat (Fiqi mana mah?) ditandai dengan kata "mana" serta ada tanda tanya. Kalimat tanya sering muncul pada anakanak usia segini karena rasa ingin tahu yang sangat tinggi.

- Kata “engga "pada kalimat “engga mau ini ,maunya itu “ merupakan ciri kalimat negatif berupa penolakan terhadap sesuatu.

- Kalimat (obot dede mana mah?) termasuk kalimat interogatif ditandai dengan adanya kata "mana" dan tanya tanya,menanyakan keberadaan robotnya

- Kalimat ibu mau kerja? termasuk kalimat interogatof/pertanyaan cirinya menggunakan tanda tanya, bertanya apakah ibunya mau bekerja atau tidak.

- Kalimat Bia mau salim dulu termasuk berita memberitahu ibunya sebelum berangkatpingin salaman dulu

- Kalimat Mah ini buat apa?Termasuk kalimat pertanyaan ditandai kata "apa" dan tanda tanya.

- Kalimat "itu punya siapa?'Termasuk kalimat pertanyaan ditandai dengan kata "siapa"dan tanda tanya

- Kalimat “ jangan pegang mainanku! Termasuk kalimat negatif ditandai dengan kata "jangan"

- Kalimat "Ibu aku mau maen kelapang" Termasuk kalimat berita memberitahu ibunya bahwa dia mau main di lapang

\section{KESIMPILAN}

1. Pemerolehan bahasa secara fonologis pada anak-usia satu sampai lima tahun di kelurahan cigintung sebanyak 30 orang hampit semuanya memperoleh bunyi vokal a terutama usia satu sampai dua tahun. Untuk usia tiga sampai lima tahun 
FON ; Jurnal Pendidikan Bahasa dan Sastra Indonesia

Volume 13 Nomor 2 Tahun 2018

bertambah bunyi yang Dardjowidjojo, Soenjono.2000.Echa

diperoleh a, i, u, dan Kisah Pemerolehan Bahasa Anak

o.pemerolehan konsonannya Indonesia.Jakarta:Grasindo

yaitu bunyi bilabial nasal (m)

dan hambat $(\mathrm{p} / \mathrm{b})$ selain itu

Hamdani. 2010. Srategi Belajar

bunyi glotal, alveolar, dan

Mengajar. Bandung :Pustaka Setia.

bilabial semivokal.

2. Pemeroleh bahasa secara morfologi pada anak usia tiga sampai lima tahun, Purwanto dkk. (2007). Pengembangan pemerolehan prefiks di-, ter-.

Modul. Jakarta : Pusat Teknologi

Pemerolehan sufiks -nya, dan

Informasi dan Komunikasi

simulfiks di-an dan bentuk in.

Pendidikan

Tidak ditemukan infiks.

Reduplikasi utuh dan Ramlan. 1983. Morfologi Suatu Tinjauan

reduplikasi sebagian. Tidak Deskriptif. Yogyakarta:Universitas

ditemukan kata majemuk. Gadjah Mada

3. Pemerolehan bahasa secara Ramlan. 2005. Sintaksis.Yogyakarta:C.V. sintaksis yaitu anak dapat mengucapakan kalimat deklaratif, imperatif, interogatif, dan kalimat negatif.

\section{DAFTAR PUSTAKA}

Brown H. Douglas.2008.Prinsip

Pembelajaran Dan Pengajaran

Bahasa.Penerjemah Nor Cholis Dan

Yusi Avianto: Pearson Education

Karyono

Sugiyono.2012.Metode Penelitian

Kuantitatif, Kualitatif, Dan R\&D

.Bandung:Alfabeta

Tarugan, Henry Guntur. 2011.Pengajaran

Pemerolehan Bahasa.Bandung:

Angkasa

Tim Pengembang Pedoman Bahasa

Indonesia.2016.Pedoman Umum

Ejaan Bahasa Indonesia.Jakarta:

Badan Pengembangan dan

Pembinaan Bahasa. 